\title{
Optimasi Pemberian Lumpur Aktif dan Dolomit dalam Pengolahan Limbah Cair Pabrik Kelapa Sawit
}

\section{(Optimizing of Active Sludge and Dolomite in Processing of Liquid Waste of Palm Oil Factory)}

\author{
Erni Widayanti ${ }^{1)}$, Rijadi Subiantoro ${ }^{2) *}$, Yonathan Parapasan ${ }^{2)}$ \\ 1) Program Studi Produksi dan Manajemen Industri Perkebunan Politeknik Negeri Lampung dan \\ 2) Jurusan Budidaya Tanaman Perkebunan Politeknik Negeri Lampung, Jl. Soekarno-Hatta No. 10 \\ Rajabasa, Bandar Lampung, 35144, Telp.: (0721) 703995, Fax.: (0721) 787309 \\ E-mail: rijadisubiantoro@polinela.ac.id
}

\begin{abstract}
The palm oil mill effluent (POME) generally has very high of BOD and COD contents, so it must be processed before it is drained to the body water. The purpose of this research was to determine the capability of active sludge and dolomite rate and the combination both of them in reducing the palm oil industry liquid waste. This research was conducted in December 2016 until January 2017 at Chemical Analysis Laboratory, State Polytechnic of Lampung. This research consists of two factors. First factor was the use of active sludge (without active sludge and $1 \mathrm{~kg}$ of active sludge), and the second factor was dolomite rate $(0,3 \%, 0,6 \%$, and 0,9\% dolomite).The results obtained were calculated bassed on average repetitions then at compared with the value of initial analysis and quality standard, but the $C O D$ value is calculated based on the percentage of the reduction value, and all the observed values are presented in the graph. The results showed that the $1 \mathrm{~kg}$ active sludge treatment was more effective in degrading the wastewater than with no active sludge. The increased dose of dolomite to $0.9 \%$ combined with $1 \mathrm{~kg}$ of active sludge will be followed by an increase in $\mathrm{pH}(6,23)$ and DO $\left(0,26 \mathrm{mg}^{-1}\right)$, but decrease COD to 53,7\%, TSS to 810 mg. $l^{-1}$, turbidity value to $700 \mathrm{NTU}$, and potassium content to $4865 \mathrm{mg} . \mathrm{l}^{-1}$.
\end{abstract}

Keywords: chemical oxygen demand, dissolved oxygen, palm oil mill effluent, total suspended solid, turbidity

DOI: http://dx.doi.org/10.25181/jaip.v6i1.671

Diterima: 10 Januari 2018 / Disetujui: 25 April 2018 / Diterbitkan: 21 Mei 2018

\section{PENDAHULUAN}

Kelapa sawit (Elaeis guineensis Jacq.) merupakan komoditas andalan perekonomian Indonesia karena mampu mengumbang devisa besar bagi negara dan terbukti tetap bertahan pada saat terjadinya krisis ekonomi berkepanjangan. Peningkatan permintaan pasar terhadap crude palm oil (CPO) mendorong tumbuhnya industri kelapa sawit yang semakin pesat, tetapi limbah yang dihasilkannya juga semakin meningkat.Saat ini diperkirakan jumlah limbah cair kelapa sawit yang dihasilkan mencapai 28,7 juta ton (Krismawati, 2013).

Proses pengolahan minyak kelapa sawit akan menghasilkan tiga macam limbah cair yaitu yang berasal dari kondensat rebusan sebanyak 0,12 ton, dari centrifuge sludge 0,05 ton dan dari 
pencucian hidrosiklon (hydrocyclone) 0,02 ton atau seluruhnya berjumlah 0,19 ton dari setiap ton TBS yang diolah (Lubis, 1992). Limbah cair industri menjadi ancaman serius karena limbah tersebut dipastikan mencemari lingkungan khususnya badan air dan dapat berfungsi sebagai media pembawa bibit penyakit. Limbah cair kelapa sawit masih mengandung banyak padatan terlarut, sebagian besar padatan terlarut berasal dari material lignoselulosa yang mengandung minyak (Irvan et al., 2012).

Salah satu cara pengolahan limbah yang dapat diaplikasikan dalam pengolahan limbah cair kelapa sawit yaitu pengolahan secara biologi yang dikenal sebagai biodegradasi, sebagai suatu proses oksidasi senyawa organik oleh mikroorganisme, baik di tanah, perairan, atau pada instalasi pengolahan limbah (Reynold, 1982). Proses biodegradasi limbah cair yang umum dilakukan menggunakan lumpur aktif, sebagai suatu proses biologi dalam pengolahan limbah cair, dengan pencampuran antara limbah cair dengan lumpur aktif (Moertinah et al., 2010). Padatan biologi yang aktif tersebut akan menguraikan bahan organik yang ada pada limbah cair tersebut. Bakteri pengurai tersebut bekerja pada kisaran pH 6,6 - 7,6 dengan pH optimum 7 (Rakhmawati, 2012).

Pada pengolahan limbah cair, penambahan kapur dapat menyerap (mengadsorbsi) senyawa-senyawa organik yang ada di dalam limbah, selain itu kapur juga berperan dalam meningkatkan $\mathrm{pH}$ air limbah.dan $\mathrm{pH}$ limbah semakin naik apabila penambahan konsentrasi kapur semakin tinggi (Isyuniarto et al., 2007). Tujuan penelitian ini adalah untuk menentukan kemampuan lumpur aktif dan dosis dolomit serta kombinasi antara keduanya dalam mengurangi limbah cair kelapa sawit.

\section{METODE PENELITIAN}

Penelitian ini telah dilaksanakan di Laboratorium Analisis Kimia Politeknik Negeri Lampung, mulai dari November 2016 sampai dengan Januari 2017. Bahan yang digunakan adalah limbah cair kelapa sawit inlet kolam anaerob IPAL pabrik kelapa sawit (PKS) Bekri dan lumpur aktif dari inlet kolam anaerob IPAL PKS Bekri, dolomit, $\mathrm{K}_{2} \mathrm{Cr}_{2} \mathrm{O}_{7}, \mathrm{H}_{2} \mathrm{SO}_{4} 0,01 \mathrm{~N}, \mathrm{HCl}, \mathrm{HgSO}_{4}$, $\mathrm{AgSO}_{4}$, Larutan B, pereaksi asam, Larutan b, akuades dan asam nitrat pekat Adapun alat yang digunakan yaitu ember, kran, pipet, open, spektrofotometer, DO-meter, pH-meter, erlemeyer, alat pengaduk, gelas ukur, neraca analitik, spektrofotometer, dan tabung reaksi.

Penelitian ini merupakan percobaan faktorial dengan dua faktor. Faktor pertama adalah pemberian lumpur aktif yang terdiri atas dua taraf, yaitu $0 \mathrm{~kg}\left(\mathrm{~L}_{0}\right)$ dan $1 \mathrm{~kg}\left(\mathrm{~L}_{1}\right)$. Faktor kedua adalah dosis dolomit yang terdiri atas empat taraf, yaitu: $0 \%\left(\mathrm{~K}_{0}\right), 0,3 \%\left(\mathrm{~K}_{1}\right), 0,6 \%\left(\mathrm{~K}_{2}\right)$,dan $0,9 \%$ $\left(\mathrm{K}_{3}\right)$. Dalam penelitian ini, pengolahan limbah cair secara aerob system batc dikondisikan stagnant dengan skala laboratorium, dan hasil yang diperoleh diuji secara deskriptif. Jumlah limbah cair yang digunakan pada penelitian ini yaitu $25 \mathrm{~kg}$ per ember dan perlakuan yang diberikan pada limbah cair pengolahan CPO dan PKO yang berasal dari kolam anaerob PKS Bekri, Lampung Tengah.

20 Jurnal AIP Volume 6 No. 1 | Mei 2018: 19-28 


\section{Pelaksanaan Penelitian}

Langkah pertama yang dilakukan yaitu persiapan alat dan bahan berupa ember dan diberi kran dengan jarak dari dasar ember $\pm 10-20 \mathrm{~cm}$. Ember digunakan untuk menampung limbah. Sampel diambil di bagian atas endapan yaitu pada bagian atas air limbah. Lumpur aktif dan dolomit mulai ditambahkan kedalam perlakuan setelah analisis awal sampel selesai dilaksanakan, limbah cair dan lumpur aktif berasal dari inlet kolam anaerob dan kolam aerob IPAL Bekri, Lampung Tengah. Selanjutnya setelah analisis awal sampel selesai, dilakukan pengadukan limbah selama 1 menit masing masing perlakuan dilakukan setiap hari. Pengamatan variabel pada limbah cair pengolahan kelapa sawit dilakukan 10 hari sekali sebanyak 5 kali dan dilakukan secara duplo. Adapun variabel pengamatan, yaitu COD, DO, pH, K, TSS, dan turbidity. Prosedur pengamatan mengacu pada Sanjaya et al. (2017).

\section{HASIL DAN PEMBAHASAN}

\section{Derajat Kemasaman (pH)}

Gambar 1 menunjukkan bahwa secara umum pada masing masing perlakuan terjadi peningkatan $\mathrm{pH}$ setiap 10 hari, dan peningkatan $\mathrm{pH}$ pada pengamatan ke-4 (hari ke-40) paling tinggi terjadi pada perlakuan $1 \mathrm{~kg}$ lumpur aktif dan penambahan $0,9 \%$ dolomit (LOK3) yaitu mencapai 6,32. Menurut Isyuniarto (2007), semakin besar konsentrasi kapur yang digunakan maka semakin besar peningkatan $\mathrm{pH}$, dan semakin tinggi pula penurunan COD, BOD, dan TSS pada limbah tersebut, sehingga pertumbuhan bakteri menjadi lebih baik.

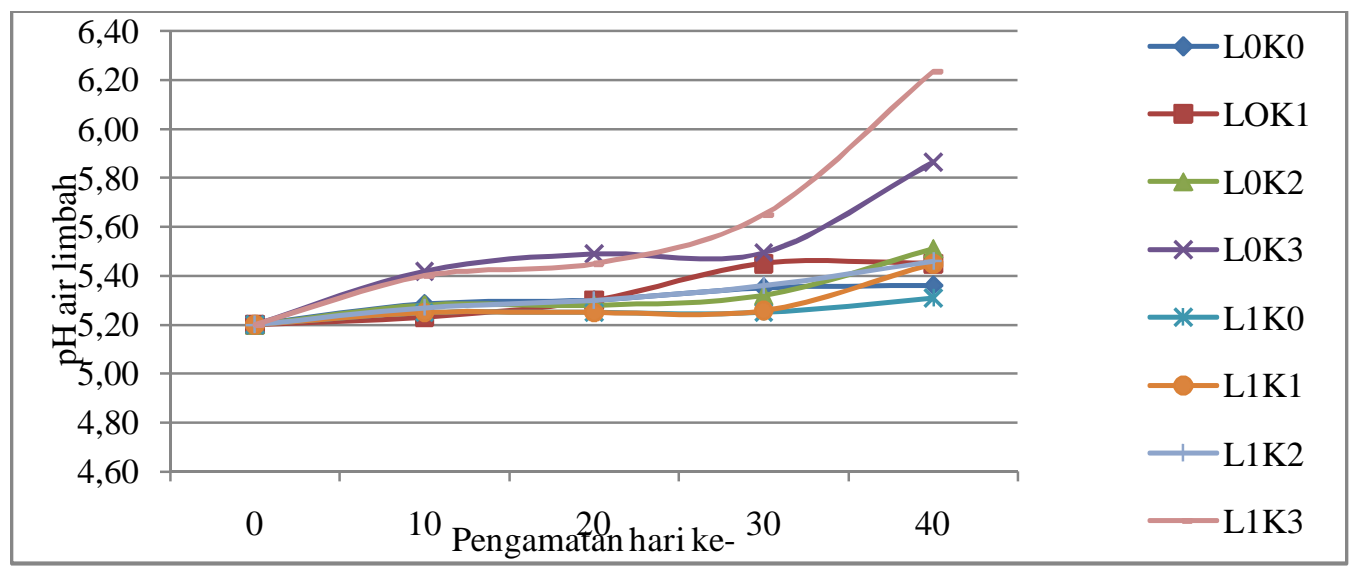

Keterangan: $\mathrm{L}_{0} \mathrm{~K}_{0}=$ kontrol; $\mathrm{L}_{0} \mathrm{~K}_{1}=$ tanpa lumpur aktif dengan penambahan $0,3 \%$ dolomit; $\mathrm{L}_{0} \mathrm{~K}_{2}=$ tanpa lumpur aktif dengan penambahan $0,6 \%$ dolomit; $\mathrm{L}_{0} \mathrm{~K}_{3}=$ tanpa lumpur aktif dengan penambahan $0,9 \%$ dolomit; $\mathrm{L}_{1} \mathrm{~K}_{0}=1 \mathrm{~kg}$ lumpur aktif dengan penambahan $0 \%$ dolomit; $\mathrm{L}_{1} \mathrm{~K}_{1}=1 \mathrm{~kg}$ lumpur aktif dengan penambahan $0,3 \%$ dolomit; $\mathrm{L}_{1} \mathrm{~K}_{2}=1 \mathrm{~kg}$ lumpur aktif dengan penambahan $0,6 \%$ dolomit; $\mathrm{L}_{1} \mathrm{~K}_{3}=1 \mathrm{~kg}$ lumpur aktif dengan penambahan $0,9 \%$ dolomit

Gambar 1. Nilai pH pada berbagai perlakuan selama percobaan 
Perlakuan yang menunjukkan peningkatan nilai $\mathrm{pH}$ yang terendah yaitu perlakuan $1 \mathrm{~kg}$ lumpur aktif dan penambahan $0 \%$ dolomit. Hal ini terjadi karena tidak ada penambahan dolomit sehingga $\mathrm{pH}$ air limbah tidak meningkat dan menyebabkan mikroorganisme tidak bekerja dengan baik. Menurut Rakhmawati (2012), bakteri tidak bekerja baik pada $\mathrm{pH}$ rendah, bakteri bekerja pada kisaran $\mathrm{pH}$ 6,6-7,6 dengan $\mathrm{pH}$ optimum 7. Setiap perlakuan pada pengamatan terakhir masih memiliki nilai $\mathrm{pH}$ yang rendah jika dibandingkan dengan baku mutu (6-9), kecuali perlakuan $1 \mathrm{~kg}$ lumpur aktif. Belum tercapainya $\mathrm{pH}$ baku mutu pada perlakuan di atas diduga akibat kondisi tempat hidup mikroba belum optimal untuk mendukung aktivitas mikroba tersebut.

\section{Dissolved Oxygen (DO)}

Gambar 2 menunjukkan bahwa pada setiap perlakuan terjadi peningkatan nilai DO setiap 10 hari, peningkatan DO pada pengamatan ke-3 (hari ke-30) paling tinggi terjadi pada perlakuan penambahan $1 \mathrm{~kg}$ lumpur aktif dan penambahan 0,9\% dolomit (L1K3) yaitu mencapai 0,25 mg.1 ${ }^{-1}$. Peningkatan ini disebabkan $\mathrm{pH}$ limbah cair tersebut lebih tinggi dibandingkan perlakuan lainnya yaitu sebesar 5,65 sehingga bakteri lebih baik dalam mendegradasi bahan organik. Jika kandungan bahan organik rendah maka kekeruhan akan menjadi rendah pula dan mengakibatkan cahaya dapat masuk ke dalam air limbah sehingga terjadi aktifitas fotosintesis oleh tanaman air sehingga DO akan naik.

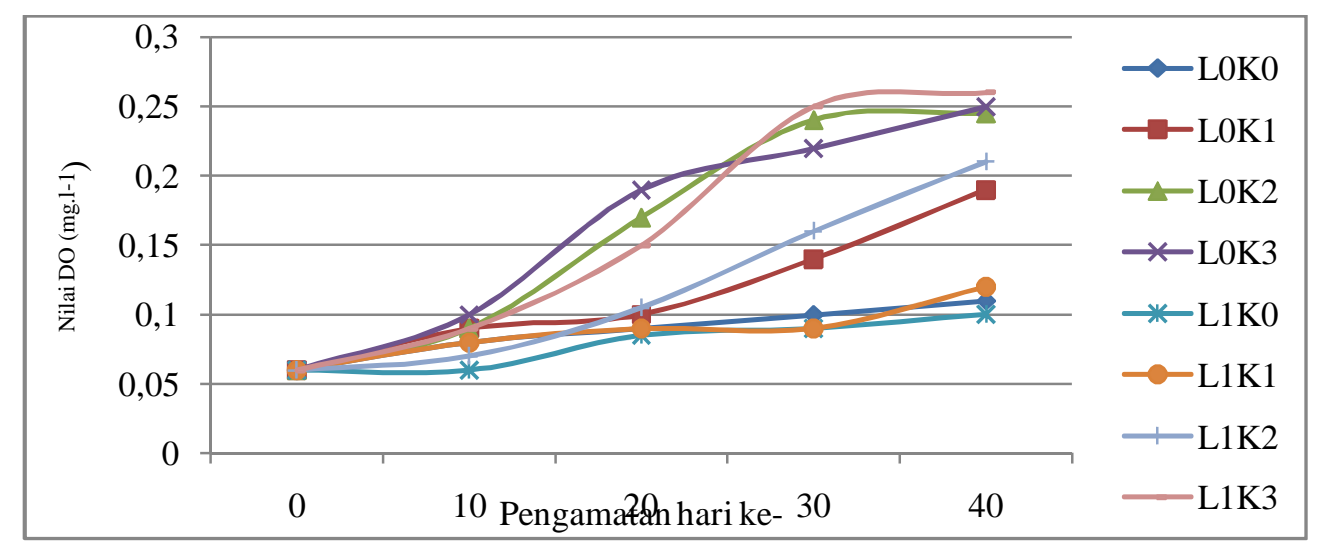

Keterangan: $\mathrm{L}_{0} \mathrm{~K}_{0}=$ kontrol; $\mathrm{L}_{0} \mathrm{~K}_{1}=$ tanpa lumpur aktif dengan penambahan 0,3\% dolomit; $\mathrm{L}_{0} \mathrm{~K}_{2}=$ tanpa lumpur aktif dengan penambahan $0,6 \%$ dolomit; $\mathrm{L}_{0} \mathrm{~K}_{3}=$ tanpa lumpur aktif dengan penambahan $0,9 \%$ dolomit; $\mathrm{L}_{1} \mathrm{~K}_{0}=1 \mathrm{~kg}$ lumpur aktif dengan penambahan $0 \%$ dolomit; $\mathrm{L}_{1} \mathrm{~K}_{1}=1 \mathrm{~kg}$ lumpur aktif dengan penambahan $0,3 \%$ dolomit; $\mathrm{L}_{1} \mathrm{~K}_{2}=1 \mathrm{~kg}$ lumpur aktif dengan penambahan $0,6 \%$ dolomit; $\mathrm{L}_{1} \mathrm{~K}_{3}=1 \mathrm{~kg}$ lumpur aktif dengan penambahan $0,9 \%$ dolomit

Gambar 2. Nilai DO pada berbagai perlakuan selama percobaan

Pada pengamatan terakhir (hari ke-40), perlakuan penambahan $1 \mathrm{~kg}$ lumpur aktif dan penambahan 0,9\% dolomit memiliki nilai DO tertinggi yaitu sebesar 0,26 selain disebabkan oleh pH yang sudah mendekati netral yaitu 6,23 hal ini juga karena bahan organik telah terdekomposisi 
dengan baik dibandingkan dengan perlakuan lainya. Menurut Nursanti (2013), untuk menaikkan jumlah oksigen terlarut pada air salah satunya yaitu dengan mengurangi jumlah bahan organik, karena jika jumlah bahan organik tinggi maka jumlah oksigen terlarut menjadi rendah, dan sebaliknya jika jumlah bahan organik rendah maka jumlah oksigen terlarut tinggi.

Setiap perlakuan pada pengamatan terakhir masih memiliki nilai DO yang rendah belum memenuhi baku mutu yang ditentukan yaitu 4, hal ini disebabkan oleh masih banyak terdapat bahan organik yang belum terdekomposisi. Menurut Makmur (2012), Semakin sedikit konsentrasi oksigen terlarut di dalam air limbah mencirikan adanya pencemaran bahan organik yang tinggi.

\section{Total Suspended Solid (TSS)}

Gambar 3 menunjukkan bahwa secara umum pada setiap perlakuan terjadi penurunan TSS setiap 10 hari, penurunan TSS pada pengamatan ke-2 (hari ke-20) paling tinggi terjadi pada perlakuan tanpa perlakuan $\left(\mathrm{L}_{0} \mathrm{~K}_{0}\right)$. Peningkatan ini terjadi karena pada limbah cair tersebut tidak ditambahkan lumpur aktif sehingga bahan organik dan TSS yang terkandung didalamnya rendah. Pada dasarnya lumpur aktif mengandung partikel organik, partikel anorganik dan sel bakteri.

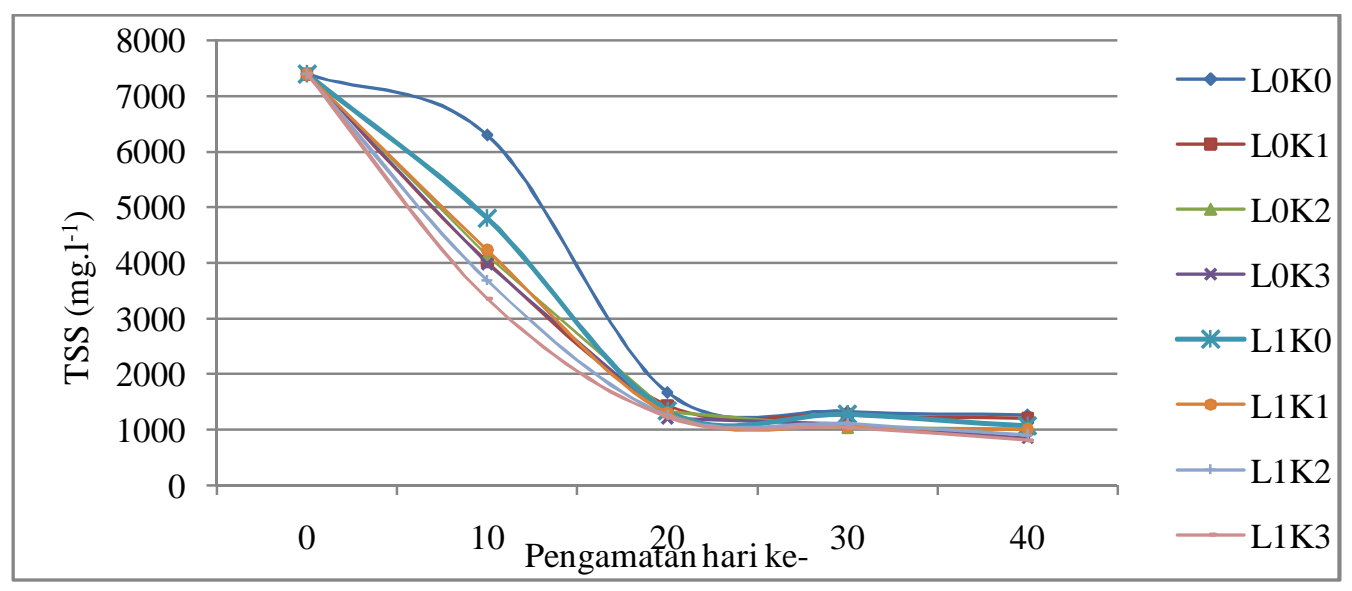

Keterangan: $\mathrm{L}_{0} \mathrm{~K}_{0}=$ kontrol; $\mathrm{L}_{0} \mathrm{~K}_{1}=$ tanpa lumpur aktif dengan penambahan $0,3 \%$ dolomit; $\mathrm{L}_{0} \mathrm{~K}_{2}=$ tanpa lumpur aktif dengan penambahan $0,6 \%$ dolomit; $\mathrm{L}_{0} \mathrm{~K}_{3}=$ tanpa lumpur aktif dengan penambahan $0,9 \%$ dolomit; $\mathrm{L}_{1} \mathrm{~K}_{0}=1 \mathrm{~kg}$ lumpur aktif dengan penambahan $0 \%$ dolomit; $\mathrm{L}_{1} \mathrm{~K}_{1}=1 \mathrm{~kg}$ lumpur aktif dengan penambahan $0,3 \%$ dolomit; $\mathrm{L}_{1} \mathrm{~K}_{2}=1 \mathrm{~kg}$ lumpur aktif dengan penambahan $0,6 \%$ dolomit; $\mathrm{L}_{1} \mathrm{~K}_{3}=1 \mathrm{~kg}$ lumpur aktif dengan penambahan $0,9 \%$ dolomit

Gambar 3. Nilai TSS pada berbagai perlakuan selama percobaan

Pengamatan terakhir (hari ke-40) menunjukkan bahwa nilai TSS terendah yaitu pada perlakuan penambahan $1 \mathrm{~kg}$ lumpur aktif dan penambahan 0,9\% dolomit yaitu sebesar $810 \mathrm{mg} . \mathrm{l}^{-1}$, hal ini disebabkanbakteri telah menguraikan padatan sehingga nilai TSS menurun dengan bertambahnya hari tinggal. Hasil penelitian ini sejalan dengan penelitian Irvan et al. (2012) bahwa 
bakteri akan mengurai padatan yang terkandung dalam POME dan mengubahnya menjadi zat makanan, sehingga nilai TSS pada tangki akan semakin menurun seiring dengan bertambahnya hari tinggal. Hasil akhir pada pengamatan ke-40 menunjukkan bahwa limbah cair tersebut masih memiliki kandungan TSS yang tinggi, jadi belum memenuhi baku mutu yang ditentukan yaitu sebesar $300 \mathrm{mg} . \mathrm{l}^{-1}$, hal ini menyebabkan tingginya nilai kekeruhan pada akhir pengamatan.

\section{Turbidity}

Secara umum pengamatan ke-10 dan ke-20 memiliki presentase penurunan turbidity yang cukup tinggi pada setiap perlakuan.Hal ini karena nilai TSS pada pengamatan tersebut juga tinggi,namun perlakuan yang memiliki penurunan kandungan turbidity tertinggi yaitu pada limbah cair tanpa perlakuan (pengamatan ke-20) yaitu sebesar 69,8\%, hal ini terjadi karena nilai TSS pada pengamatan ke-20 juga mengalami penurunan tertinggi, sehingga kekeruhan menjadi rendah karena nilai TSS berbanding lurus dengan tingkat kekeruhan.

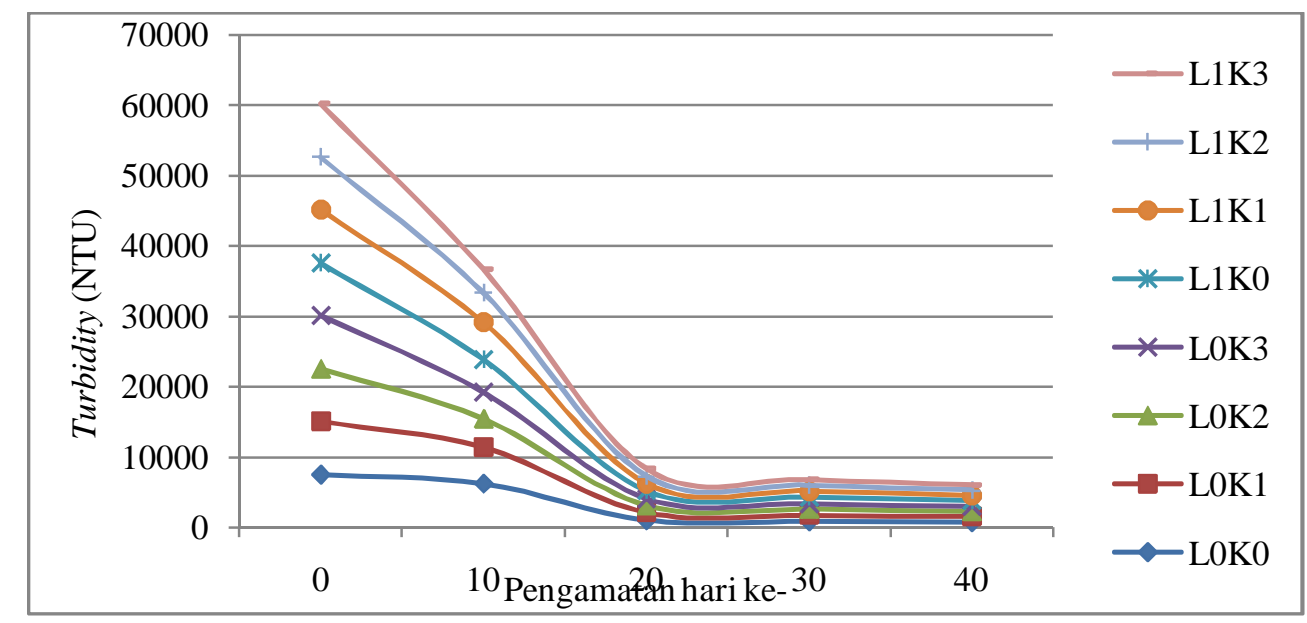

Keterangan: $\mathrm{L}_{0} \mathrm{~K}_{0}=$ kontrol; $\mathrm{L}_{0} \mathrm{~K}_{1}=$ tanpa lumpur aktif dengan penambahan 0,3\% dolomit; $\mathrm{L}_{0} \mathrm{~K}_{2}=$ tanpa lumpur aktif dengan penambahan $0,6 \%$ dolomit; $\mathrm{L}_{0} \mathrm{~K}_{3}=$ tanpa lumpur aktif dengan penambahan $0,9 \%$ dolomit; $\mathrm{L}_{1} \mathrm{~K}_{0}=1 \mathrm{~kg}$ lumpur aktif dengan penambahan $0 \%$ dolomit; $\mathrm{L}_{1} \mathrm{~K}_{1}=1 \mathrm{~kg}$ lumpur aktif dengan penambahan $0,3 \%$ dolomit; $\mathrm{L}_{1} \mathrm{~K}_{2}=1 \mathrm{~kg}$ lumpur aktif dengan penambahan $0,6 \%$ dolomit; $\mathrm{L}_{1} \mathrm{~K}_{3}=1 \mathrm{~kg}$ lumpur aktif dengan penambahan $0,9 \%$ dolomit

Gambar 4. Nilai turbidity pada berbagai perlakuan selama percobaan

Hal ini disebabkan oleh adanya bakteri didalam lumpur aktif pada $\mathrm{pH}$ yang tinggi mampu menguraikan partikel-partikel yang berada dalam limbah cair kelapa sawit. Nursanti (2013) menyatakan bahwa lumpur aktif mampu memberikan kontribusi dalam proses penguraian partikel pada limbah cair sehingga dapat menurunkan tingkat kekeruhan. Nilai turbidity tertinggi pada pengamatan terakhir yaitu perlakuan tanpa lumpur aktif dan penambahan $0 \%$ dolomit yaitu sebesar 812 NTU, hal ini disebabkan $\mathrm{pH}$ pada perlakuanini masih rendah sehingga bakteri dan mikro organisme tidak bekerja secara maksimal dibandingkan dengan perlakuan lain.

24 Jurnal AIP Volume 6 No. 1| Mei 2018: 19-28 
Setiap perlakuan pada pengamatan terakhir masih memiliki nilai turbidity yang tinggi.Hal ini terjadi karena pada masing-masing perlakuan masih memiliki kandungan TSS dan padatan yang tinggi pula. Menurut Yusuf (2008), limbah cair yang memiliki tingkat kekeruhan yang tinggi masih berbahaya bagi biota didalamnya hal ini disebabkan oleh kekeruhan yang tinggi dapat menghambat aktivitas dan proses metabolisme didalamnya.

\section{Kalium}

Gambar 5 menunjukkan secara umum pada setiap perlakuan terjadi peningkatan pada pengamatan ke-10 hari setelah aplikasi perlakuan. Hal ini terjadi karena penambahan lumpur aktif berkontribusi dalam meningkatkan nilai kalium karena didalam lumpur aktif banyak mengandung kalium. Selanjutnya setiap perlakuan mengalami penurunan pada pengamatan ke-20 sampai hari ke 40 setelah perlakuan. Menurut Budianta (2005), jika limbah cair kelapa sawit dibiarkan terdegradasi lebih lanjut maka unsur hara yang ada (N, P, dan K) akan dimanfaatkan oleh mikroorganisme untuk hidup dan berkembang sehingga hara yang ada akan menurun. Selain itu menurut Nursanti (2013), penurunan kadarN, P, dan K terjadi karena adanya reduksi efluen limbah menjadi gas yang terbuang dan penguraian bahan organik dimanfaatkan sebagai sumber energi bakteri perombak, serta pembentukan sel atau biomasa baru. Diduga penurunan unsur hara $\mathrm{P}$ dan $\mathrm{K}$ terjadi karena kedua unsur tersebut bersenyawa dengan bahan lain sehingga mengendap dibagian bawah ember (wadah perlakuan).

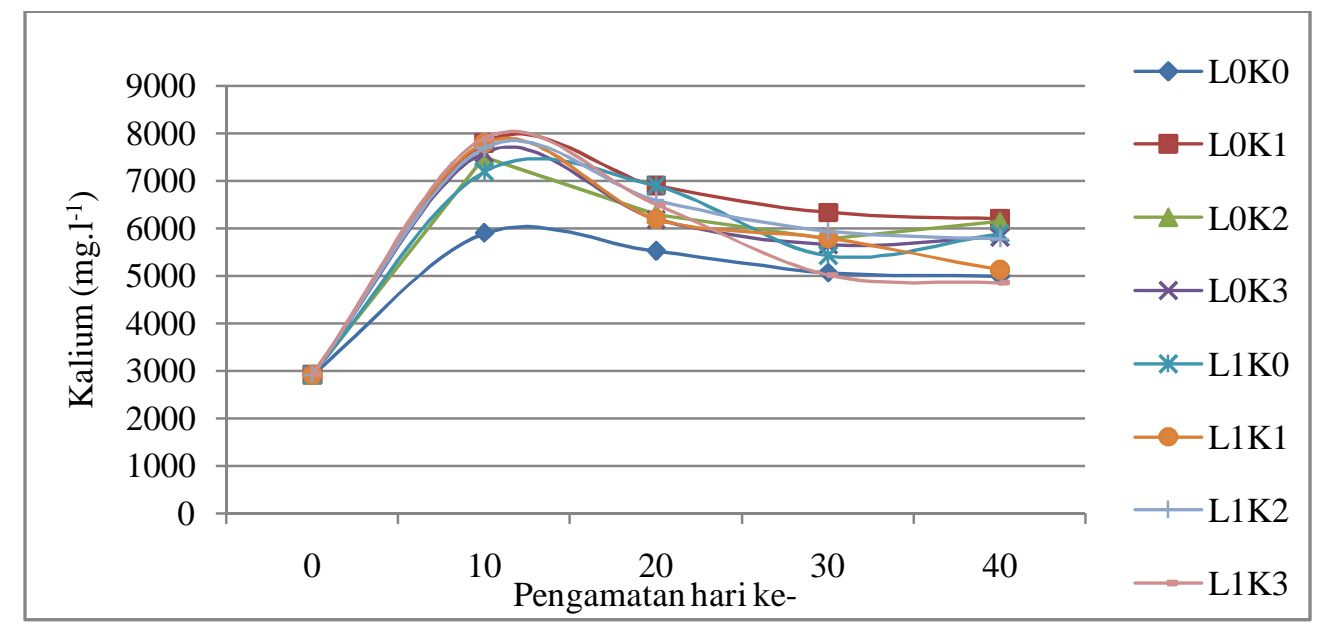

Keterangan: $\mathrm{L}_{0} \mathrm{~K}_{0}=$ kontrol; $\mathrm{L}_{0} \mathrm{~K}_{1}=$ tanpa lumpur aktif dengan penambahan $0,3 \%$ dolomit; $\mathrm{L}_{0} \mathrm{~K}_{2}=$ tanpa lumpur aktif dengan penambahan $0,6 \%$ dolomit; $\mathrm{L}_{0} \mathrm{~K}_{3}=$ tanpa lumpur aktif dengan penambahan $0,9 \%$ dolomit; $\mathrm{L}_{1} \mathrm{~K}_{0}=1 \mathrm{~kg}$ lumpur aktif dengan penambahan $0 \%$ dolomit; $\mathrm{L}_{1} \mathrm{~K}_{1}=1 \mathrm{~kg}$ lumpur aktif dengan penambahan $0,3 \%$ dolomit; $\mathrm{L}_{1} \mathrm{~K}_{2}=1 \mathrm{~kg}$ lumpur aktif dengan penambahan $0,6 \%$ dolomit; $\mathrm{L}_{1} \mathrm{~K}_{3}=1 \mathrm{~kg}$ lumpur aktif dengan penambahan $0,9 \%$ dolomit

Gambar 5. Nilai kalium pada berbagai perlakuan selama percobaan 
Perlakuan dengan penambah $1 \mathrm{~kg}$ lumpur aktif dan penambahan $0,9 \%$ pada hari ke 40 setelah perlakuan memiliki kandungan kalium terendah yaitu $4865 \mathrm{mg} / \mathrm{l}$ sedangkan perlakuan tanpa lumpur aktif dan penambahan $0,3 \%$ dolomit pada hari ke 40 setelah perlakuan memiliki kandungan kalium tertinggi yaitu 6206 mg. ${ }^{-1}$.Menurut Askridayani (2006), POME merupakan suspensi organik yang selain dapat menyumbang hara $\mathrm{P}$ dan $\mathrm{N}$ limbah cair kelapa sawit juga menyumbang hara K. Pada pengamatan terakhir masing masing perlakuan mengandung kalium yang cukup tinggi hal ini terjadi karena limbah cair kelapa sawit banyak mengandung unsur hara $\mathrm{N}$, $\mathrm{P}$, dan $\mathrm{K}$ sehingga limbah cair tersebut dapat dimanfaatkan untuk canpuran pupuk organik untuk meningkatkan unsur hara.

\section{Chemical Oxygen Demand (COD)}

Gambar 6 menunjukkan bahwa pada setiap perlakuan terjadi penurunan persentase nilai COD. Pada pengamatan hari ke-40, perlakuan dengan penurunan persentase COD tertinggi yaitu pada perlakuan penambahan $1 \mathrm{~kg}$ lumpur aktif dan penambahan 0,9\% dolomit 53,37\%. Hal ini disebabkan $\mathrm{pH}$ limbah cair mendekati netral yaitu sebesar 6,23 karena adanya penambahan $1 \mathrm{~kg}$ lumpur aktif dan 0,9\% dolomit sehingga mikroorganisme lebih baik dalam mendekomposisi bahan organik dibandingkan dengan perlakuan lainnya. Menurut Rakhmawati (2012), bakteri bekerja pada kisaran $\mathrm{pH}$ 6,6-7,6 dengan $\mathrm{pH}$ optimum 7. Kenaikan $\mathrm{pH}$ juga dipengaruhi oleh konsentrasi dolomit..Menurut Isyuniarto (2007), semakin besar konsentrasi kapur yang digunakan maka semakin besar pula penurunan COD, BOD dan TSS pada limbah.

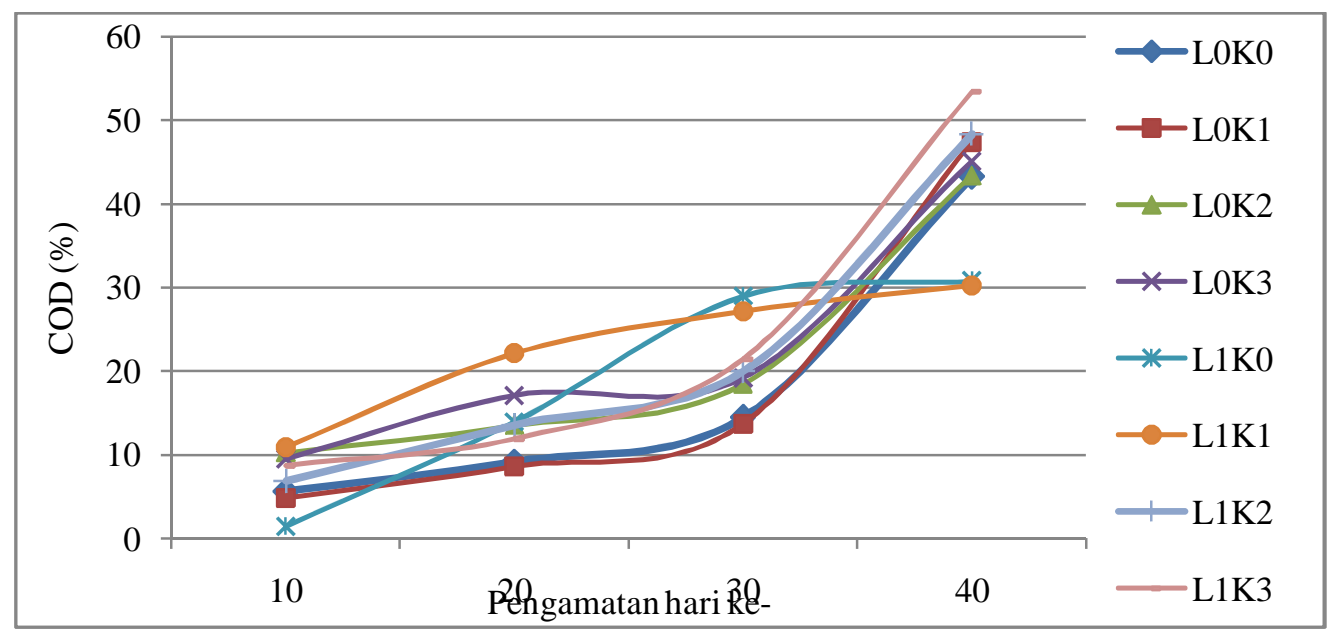

Keterangan: $\mathrm{L}_{0} \mathrm{~K}_{0}=$ kontrol; $\mathrm{L}_{0} \mathrm{~K}_{1}=$ tanpa lumpur aktif dengan penambahan $0,3 \%$ dolomit; $\mathrm{L}_{0} \mathrm{~K}_{2}=$ tanpa lumpur aktif dengan penambahan $0,6 \%$ dolomit; $\mathrm{L}_{0} \mathrm{~K}_{3}=$ tanpa lumpur aktif dengan penambahan $0,9 \%$ dolomit; $\mathrm{L}_{1} \mathrm{~K}_{0}=1 \mathrm{~kg}$ lumpur aktif dengan penambahan $0 \%$ dolomit; $\mathrm{L}_{1} \mathrm{~K}_{1}=1 \mathrm{~kg}$ lumpur aktif dengan penambahan $0,3 \%$ dolomit; $\mathrm{L}_{1} \mathrm{~K}_{2}=1 \mathrm{~kg}$ lumpur aktif dengan penambahan $0,6 \%$ dolomit; $\mathrm{L}_{1} \mathrm{~K}_{3}=1 \mathrm{~kg}$ lumpur aktif dengan penambahan $0,9 \%$ dolomit

Gambar 6. Nilai COD pada berbagai perlakuan selama percobaan 
Peningkatan reduksi COD pada perlakuan $1 \mathrm{~kg}$ lumpur aktif $+0,9 \%$ dolomit juga dipengaruhi oleh pemberian lumpur aktif yang didalamnya mengandung bakteri dan mikroorganisme yang dapat mereduksi polutan limbah cair. Krismawati (2013) berpendapat bahwa semakin besar persentase volume lumpur aktif maka efisiensi penurunan COD nya semakin besar.Hal ini disebabkan oleh banyaknya bakteri anaerob sehingga dekomposisibahan organik yang terkandung dalam air limbah semakin meningkat dan semakin banyak lumpur aktif maka semakin banyak bakteri yang terkandung didalam lumpur tersebut. Sani (2006) juga berpendapat bahwa jika volume lumpur aktif lebih besar maka mikroba lebih banyak sehingga senyawa organik dalam air limbah yang didegradasi oleh mikroba juga semakin banyak, akibatnya penurunan COD semakin besar. Selain lumpur aktif, waktu tinggal limbah cair juga mempengaruhi reduksi COD, semakin lama waktu tinggal maka semakin tinggi reduksi COD.

Perlakuan yang menunjukkan penurunan persentase nilai COD yang terendah yaitu perlakuan dengan tanpa lumpur aktif dan penambahan $0,3 \%$ dolomit, hal ini terjadi karena pada perlakuan tersebut limbah cair memiliki $\mathrm{pH}$ rendah yaitu 5,43 sehingga pertumbuhan bakteri tehambat dalam mendekomposisi bahan organik. Hasil akhir pada pengamatan ke-40, setiap perlakuan masih memiliki nilai COD yang tinggi, belum memenuhi baku mutu yang ditentukan yaitu 500. Hal ini terjadi karena $\mathrm{pH}$ limbah cair dan DO masih rendah dan masih banyak terdapat bahan organik yang belum terdekomposisi.

\section{KESIMPULAN}

Penggunaan lumpur aktif dalam mereduksi polutan limbah cair kelapa sawit (POME) lebih efektif dibanding tanpa lumpur aktif. Dosis dolomit tertinggi $(0,9 \%)$ yang diberikan menghasilkan nilai pH 5,87 dan DO 0,25 mg. $1^{-1}$, mampu menurunkan COD menjadi 45,13\%, nilai TSS menjadi $847 \mathrm{mg} . \mathrm{l}^{-1}$, nilai turbidity menjadi $738 \mathrm{NTU}$, dan kalium menjadi $5820 \mathrm{mg} \cdot \mathrm{l}^{-1}$. Dosis dolomit tertinggi $(0,9 \%)$ yang dikombinasikan dengan $1 \mathrm{~kg}$ lumpur aktif menghasilkan nilai $\mathrm{pH}(6,23)$ dan DO (0,26 mg..$\left.^{-1}\right)$ yang lebih tinggi, tetapi mampu menurunkan COD menjadi 53,7\%, nilai TSS menjadi $810 \mathrm{mg} . \mathrm{l}^{-1}$, nilai turbidity menjadi $4865 \mathrm{NTU}$, dan kalium menjadi $4865 \mathrm{mg} . \mathrm{l}^{-1}$.

\section{UCAPAN TERIMA KASIH}

Penulis mengucapkan terimakasih kepada Ir. Fatahillah, M.P. selaku penguji yang telah memberikan kritik dan saran serta kepada PTPN VII Unit Bekri yang telah membantu memberikan sampel limbah cair kelapa sawit. 


\section{DAFTAR PUSTAKA}

Budianta, D. (2005). Potensi Limbah Cair Pabrik kelapa Sawit Sebagai Sumber Hara Untuk Tanaman Perkebunan (Potential of Palm Oil Mill Effluent for Organic Fertilizer on Plantation Plant). Dinamika Pertanian, 20(1), 273-282.

Sani, E. Y. (2006). Pengolahan air limbah tahu menggunakan Reaktor anaerob bersekat dan aerob (Doctoral dissertation, program Pascasarjana Universitas Diponegoro).

Irvan, B. T., Vincent, M., \& Tandean, Y. (2012). Pengolahan Lanjut Limbah Cair Kelapa Sawit Secara Aerobik Menggunakan Effective Microorganism Guna Mengurangi Nilai TSS. Jurnal Teknik Kimia USU, 1(2), 27-30.

Isyuniarto, Usada, W., \& Purwadi, A. (2007). Degradasi limbah cair industri kertas menggunakan oksidan ozon dan kapur. In: Prosiding PPI - PDIPTN. pp 55-60.

Krismawati, R., Ahdia, R., \& Soetrisnanto, D. (2013). Pengolahan Efluen Pond Fakultatif Anaerobik IPAL Industri Kelapa Sawit secara Fakultatif Anaerobik-Fitoremediasi sebagai Pre-Treatment Media Tumbuh Algae. Jurnal Teknologi Kimia dan Industri, 2, 286-294.

Lubis, A. U. (2008). Kelapa Sawit (Elaeis guineensis Jacq.) di Indonesia. Marihat: Pusat Penelitian Kelapa Sawit.

Makmur, M., Kusnoputranto, H., Moersidik, S. S., \& Wisnubroto, D. S. (2013). Pengaruh limbah organik dan rasio $\mathrm{n} / \mathrm{p}$ terhadap kelimpahan fitoplankton di kawasan budidaya kerang hijau Cilincing. Jurnal Teknologi Pengelolaan Limbah, 15(2), 51-64.

Moertinah, S., Yuliastuti, R., \& Yuliasni, R. (2010). Peningkatan kinerja lumpur aktif dengan penambahan karbon aktif dalam pengolahan air limbah industri tekstil pewarnaan dengan zat warna indigo \& sulfur. Journal of Industrial Research (Jurnal Riset Industri), 4(1), 23-33.

Nursanti, I., Dedik, B., Napoleon, A., \& Yakup, P. (2013, November). Pengolahan Limbah Cair Pabrik Kelapa Sawit Kolam Anaerob Sekunder I menjadi Pupuk Organik melalui Pemberian Zeolit. In: Seminar Nasional Sains \& Teknologi V. Lembaga Penelitian Universitas Lampung. pp. 616-626.

Reynolds, T. D. (1982). Unit Operations and Processes in Environmental Engineering. Belmont, California: Wadsworth Inc.

Sanjaya, R., Subiantoro, R., \& Supriyatdi, D. (2017). Efektivitas Kombinasi Lumpur Aktif dan Natrium Bikarbonat (NaHCO3) dalam Pengelolaan Limbah Cair Industri Tebu (Saccharum officinarum L.). Jurnal Agro Industri Perkebunan, 5(1), 39-56.

Rakhmawati, D. (2012). Remediasi Limbah Proses Pewarna Naptol Jeans Dengan Sistem Lumpur Aktif Menggunakan Bakteri Indigenus.Unpublished undergraduate thesis, Universitas Atma Jaya, Yogyakarta.

Yusuf, G. (2008). Bioremediasi limbah rumah tangga dengan sistem simulasi tanaman air. Bumi Lestari, 8(2), 136-144. 